\title{
Comparison of the clinical features and outcome of children with hemophagocytic lymphohistiocytosis (HLH) secondary to visceral leishmaniasis and primary HLH: a single-center study
}

\author{
Hadi Mottaghipisheh', Kurosh Kalantar ${ }^{2}$, Ali Amanati ${ }^{3}$, Mansoureh Shokripour ${ }^{4}$, Mahdi Shahriari ${ }^{{ }^{*}+}$,
}

Omid Reza Zekavat', Soheila Zareifar ${ }^{1}$, Mehran Karimi ${ }^{1}$, Sezaneh Haghpanah ${ }^{1}$ and Mohammadreza Bordbar ${ }^{{ }^{*}+}$

\begin{abstract}
Background: Hemophagocytic lymphohistiocytosis $(H L H)$ is a syndrome of excessive inflammation. We aimed to describe the clinical and laboratory findings of HLH patients secondary to Visceral leishmaniasis (VL) and their treatment outcome during a 4-year follow-up period compared to primary HLH.

Method: Forty children with primary HLH confirmed by genetic study and 20 children with HLH secondary to VL confirmed by a blood or bone marrow polymerase chain reaction from 2014 to 2018 in Shiraz, Fars province, Southern Iran, were enrolled.

Results: The median age at diagnosis was 11.5 months (range 1-170), and 56.7\% were male. Fever and splenomegaly were the most frequent clinical presentations. 93.3\% of the subjects had an HScore $>169$, which had a good correlation with $\mathrm{HLH}-2004$ criteria $(r=0.371, P=0.004)$. Patients with primary HLH experienced more thrombocytopenia $(P=0.012)$ and higher alanine transaminase $(P=0.016)$, while patients with $\mathrm{VL}$-associated $\mathrm{HLH}$ had higher ferritin $(P=0.034)$ and erythrocyte sedimentation rate $(P=0.011)$. Central nervous system (CNS) involvement occurred in $38.3 \%$ of patients. The mortality rate was higher in patients with CNS disease (61\% vs. $35 \%, P=0.051)$. The $3-y$ r overall survival rate was $35.9 \%$. (24\% in primary HLH and 100\% in VL-associated HLH, $P<0.001$ ). In Cox regression analysis, platelet count $<100,000 / \mu$ I (hazard ratio 4.472, 95\% confidence interval 1.324-15.107, $P=0.016$ ) correlated with increased mortality in patients with primary HLH.
\end{abstract}

Conclusion: $\mathrm{VL}$ is a potential source of secondary $\mathrm{HLH}$ in regions with high endemicity. Treatment of the underlying disease in VL-associated HLH is sufficient in most cases, with no need to start etoposide-based chemotherapy.

Keywords: Hemophagocytic lymphohistiocytosis, Visceral leishmaniosis, Prognostic factors, Survival

\footnotetext{
* Correspondence: drmahdi.shahriari@gmail.com; mbordbar53@gmail.com; bordbarm@sums.ac.ir

${ }^{+}$Mahdi Shahriari and Mohammadreza Bordbar contributed equally to this work.

${ }^{5}$ Department of Pediatrics, Nemazi Hospital, Shiraz University of Medical Sciences, Shiraz, Iran

${ }^{1}$ Hematology Research Center, Shiraz University of Medical Sciences, Shiraz, Iran

Full list of author information is available at the end of the article
}

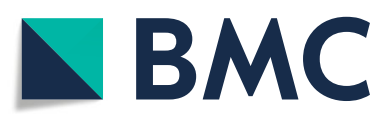

(๑) The Author(s). 2021 Open Access This article is licensed under a Creative Commons Attribution 4.0 International License, which permits use, sharing, adaptation, distribution and reproduction in any medium or format, as long as you give appropriate credit to the original author(s) and the source, provide a link to the Creative Commons licence, and indicate if changes were made. The images or other third party material in this article are included in the article's Creative Commons licence, unless indicated otherwise in a credit line to the material. If material is not included in the article's Creative Commons licence and your intended use is not permitted by statutory regulation or exceeds the permitted use, you will need to obtain permission directly from the copyright holder. To view a copy of this licence, visit http://creativecommons.org/licenses/by/4.0/. The Creative Commons Public Domain Dedication waiver (http://creativecommons.org/publicdomain/zero/1.0/) applies to the data made available in this article, unless otherwise stated in a credit line to the data. 


\section{Introduction}

Hemophagocytic lymphohistiocytosis (HLH) is a syndrome of excessive inflammation and tissue destruction due to abnormal immune activation. The absence of normal downregulation by activated macrophages and lymphocytes is possibly the cause of hyper inflammation and dysregulated immune state [1]. Infants are most commonly affected, with the highest incidence in those younger than 3 months [2].

HLH presents as a febrile illness associated with multiple organ involvement. Thus, initial signs and symptoms of HLH can mimic common infections, fever of unknown origin, hepatitis, or encephalitis [3]. Therefore, the diagnosis of HLH is primarily based on fulfilling at least 5 out of 8 criteria based on the published diagnostic criteria used in the HLH-2004 trial [4].. Similarly, homozygosity or compound heterozygosity for verified HLH-associated mutations will confirm the diagnosis [5]. Moreover, a scoring system has been developed to generate a diagnostic score referred to as "HScore," which estimates the probability of HLH (Table 1). A score higher than 169 was shown to predict the risk of HLH with $93 \%$ sensitivity and $86 \%$ specificity [6].

On the other hand, secondary (sporadic, acquired) $\mathrm{HLH}$ is generally used to describe patients without a known familial mutation who typically have a clear trigger for developing HLH. It usually follows an infectious disease caused by organisms, including Epstein-Barr virus (EBV), cytomegalovirus (CMV), hepatitis viruses, varicella infection, leishmania, Mycobacterium tuberculosis, among many others. Moreover, autoimmune and rheumatologic disorders, malignancies, and metabolic disorders may trigger the cytokine storm [7].

A few small case series of primary or secondary HLH have been reported in Iran [8-10]. Additionally, despite a high prevalence of Visceral leishmaniasis (VL) in Southern Iran [11], there are few reports of VLassociated HLH in our region $[12,13]$. Therefore, in this prospective study, we aimed to describe the clinical and laboratory findings and the outcome of children diagnosed with VL-associated HLH during a 4-year followup period compared to patients with primary HLH.

\section{Methods and materials}

\section{Study population and data acquisition}

This prospective observational study was conducted in a tertiary oncology referral center in Shiraz, Fars province in Southern Iran, 2014-2018. During the study period, patients with a confirmed diagnosis of HLH were included. HLH was diagnosed based on the diagnostic criteria proposed by the Histiocyte Society in 2004 [14].

Patients with a positive family history or with diseasecausing mutations in the genes encoding perforin (FHL2), Munc 13-4 (FHL3), Syntaxin 11 (FHL4), Munc
Table 1 HScore

\begin{tabular}{|c|c|}
\hline Parameter & Score \\
\hline \multicolumn{2}{|c|}{$\begin{array}{l}\text { Known underlying immunosuppression, HIV positive, } \\
\text { Immunosuppressive drugs }\end{array}$} \\
\hline No & 0 \\
\hline Yes & 18 \\
\hline \multicolumn{2}{|l|}{ Maximal temperature $(\mathrm{C})$} \\
\hline$<38.4$ & 0 \\
\hline $38.4-39.4$ & 33 \\
\hline$>39.4$ & 49 \\
\hline \multicolumn{2}{|l|}{ Organomegaly } \\
\hline No & 0 \\
\hline Hepatomegaly or splenomegaly & 23 \\
\hline Hepatomegaly \& splenomegaly & 38 \\
\hline \multicolumn{2}{|c|}{ Number of cytopenias ( $\mathrm{Hb} \leq 9.2 \mathrm{~g} / \mathrm{dL}, \mathrm{WBC} \leq 5000 / \mu \mathrm{l}, \mathrm{PLT} \leq 110,000 / \mu \mathrm{l})$} \\
\hline 1 lineage & 0 \\
\hline 2 lineages & 24 \\
\hline 3 lineages & 34 \\
\hline \multicolumn{2}{|l|}{ Higher ferritin level (ng/ml) } \\
\hline$<2000$ & 0 \\
\hline $2000-6000$ & 35 \\
\hline$>6000$ & 50 \\
\hline \multicolumn{2}{|l|}{ Higher triglyceride level (mg/dL) } \\
\hline$<133.5$ & 0 \\
\hline $133.5-356$ & 44 \\
\hline$>356$ & 64 \\
\hline \multicolumn{2}{|l|}{ Lower fibrinogen level (g/L) } \\
\hline$>250$ & 0 \\
\hline$\leq 250$ & 30 \\
\hline \multicolumn{2}{|l|}{ Higher SGOT/AST level (IU/L) } \\
\hline$<30$ & 0 \\
\hline$\geq 30$ & 19 \\
\hline \multicolumn{2}{|c|}{ Hemophagocytosis features on bone marrow aspirate } \\
\hline No & 0 \\
\hline Yes & 35 \\
\hline Total score & \\
\hline
\end{tabular}

HIV human immunodeficiency virus, $H b$ hemoglobin, WBC white blood cell, PLT platelet, SGOT serum glutamic-oxaloacetic transaminase, AST aspartate aminotransferase

18-2 (FHL5), Lyst (Chediak-Higashi syndrome), and Rab 27A (Griscelli syndrome type 2), signaling lymphocyte activation molecule associated protein (XLP1) and $\mathrm{X}$-linked inhibitor of apoptosis (XLP2) were defined as primary HLH. Patients with a confirmed VL diagnosis with a blood or bone marrow polymerase chain reaction (PCR) or indirect fluorescent antibody (IFA) test who fulfilled HLH-2004 criteria were defined as VLassociated HLH. In addition, information on 
demographic characteristics, clinical, laboratory, and radiological findings at presentation, treatment response, and survival outcomes were collected. HScore was calculated in each patient to estimate the probability of HLH in our patients and compare it with HLH-2004 diagnostic criteria. Participants in this study were assented to come in the survey according to the local Ethics Committee of the Shiraz University of Medical Sciences (IR.sums.med.rec. 1396.s195). A written informed consent was signed by the parents or the legal guardians of the participants.

\section{Initial diagnostic workup}

Based on our HLH-management protocol, the initial diagnostic workup included serological tests for EBV, CMV, human immunodeficiency virus, Brucella, Salmonella, and VL. In any suspected case of viralassociated HLH or leishmania-associated HLH, an additional molecular test with real-time polymerase chain reaction (RT-PCR) was requested to quantify viral or parasite load. RT-PCR provides valuable information about baseline virologic or parasitic status and is very useful for monitoring and response to treatment. The molecular diagnosis of disease was assessed with wholeexome sequencing with the next-generation sequencing (NGS) method in most study patients. The mutations found by NGS were confirmed by Sanger method.

\section{Soluble CD25 (sCD25) measurement}

sCD25 was measured using a commercial ELISA kit (Human sCD25 ELISA Ready-SET-Go, e-bioscience, USA) (sensitivity: $4 \mathrm{pg} / \mathrm{ml}$ ) based on the manufacturer's instructions. We determined the levels of sCD25 within the sample by setting up a standard curve of known target protein concentrations provided in the kit. Normal ranges for sCD25 in this study were $1.9-13.1 \mathrm{pg} / \mathrm{ml}$.

\section{CNS involvement}

CNS involvement was defined if the patients had neurologic signs and symptoms including seizure, altered level of consciousness, or focal neurologic signs in addition to one of these two conditions: 1. pleocytosis and/or proteinosis in cerebrospinal fluid or 2. radiologic abnormalities on magnetic resonance imaging (MRI) such as high signal intensity lesions, hemorrhage, atrophy, and leptomeningeal enhancement.

\section{Treatment protocol}

All of our study patients with primary HLH were treated with HLA-94-based immune-chemotherapy. Briefly, the induction regimen lasted 8 weeks, including etoposide $150 \mathrm{mg} / \mathrm{m}^{2} /$ day twice a week for 2 weeks and then once weekly for the next 6 weeks. Besides, dexamethasone 10 $\mathrm{mg} / \mathrm{m}^{2} /$ day for 2 weeks was started. The dose was halved every 2 weeks and tapered and discontinued on the last week of induction therapy. Patients with evidence of CNS disease were additionally treated with intrathecal methotrexate if the symptoms did not improve with systemic treatment. The continuation therapy included etoposide $150 \mathrm{mg} / \mathrm{m}^{2} /$ day every other week with pulses of dexamethasone $10 \mathrm{mg} / \mathrm{m}^{2} /$ day for 3 days and oral cyclosporine $6 \mathrm{mg} / \mathrm{kg} /$ day aiming at blood trough level around $200 \mathrm{mcg} / \mathrm{L}$. The treatment continued for up to 40 weeks unless hematopoietic stem cell transplantation from a matched donor was available. Most of the patients with leishmaniasis-associated HLH (94.7\%) were only treated with liposomal amphotericin B (total cumulative dose: $20 \mathrm{mg} / \mathrm{kg}$ divided into 4 or 5 doses administered in 4 or 5 days, respectively with no need to start HLH-specific therapy [15].. A minority were treated with dexamethasone $(0.15 \mathrm{mg} / \mathrm{kg} /$ dose three times a day $)$ for $3-5$ days to control the cytokine storm.

\section{Statistical analysis}

Data were analyzed by the Statistical Package for the Social Sciences (SPSS Inc., Chicago, Illinois, USA, version 23). Descriptive data were presented as median, interquartile range (IQR), and percentages. The comparison of qualitative variables among different groups was made by the Chi-square test or the Fisher exact test. Quantitative variables with non-normal distribution were compared with the non-parametric Mann-Whitney U test between two groups. The Pearson correlation tested the correlation between the 2004-HLH diagnosis criteria and HScore. Univariate analysis was used to test possible covariates associated with outcome measures, including CNS involvement, relapse, and death. Those variables with a $P$ value less than 0.2 were entered in multivariable analysis. Binary logistic regression was used to determine independent variables associated with CNS involvement and relapse. The survival curve was illustrated by the Kaplan-Mayer method. The Log-rank test evaluated a comparison of survival curves between two groups of patients. The Cox regression model was used to determine the independent variables associated with the outcome. The associations were reported as hazard ratio (HR) and 95\% confidence interval (CI). A P-value of less than 0.05 was considered statistically significant.

\section{Results}

\section{Demographic data}

Sixty patients with a confirmed diagnosis of HLH were enrolled. The clinical features and laboratory findings of patients at their initial presentation are shown in Table 2. In total, 34 patients were male with male/ female ratio = 1.30. The median age at diagnosis was 11.5 months (IQR 4-35.7 months), and 42 patients (70\%) were younger 
Table 2 Clinical features and laboratory data of patients with primary and visceral leishmaniosis-associated hemophagocytic lymphohistiocytosis

\begin{tabular}{|c|c|c|c|c|}
\hline \multirow[t]{2}{*}{ Variables } & \multirow[b]{2}{*}{$\begin{array}{l}\text { All } \\
\text { patients } \\
(n=60) \\
n(\%)\end{array}$} & \multicolumn{2}{|c|}{ HLH classification } & \multirow{2}{*}{$\begin{array}{l}P \text { - } \\
\text { Value }\end{array}$} \\
\hline & & $\begin{array}{l}\text { Primary } \\
\text { HLH ( } n= \\
40) \\
n(\%)\end{array}$ & $\begin{array}{l}\text { VL-associated } \\
\text { HLH }(n=20) \\
\text { n (\%) }\end{array}$ & \\
\hline
\end{tabular}

Age

$\begin{array}{lllll}<24 \text { months } & 42(70) & 27(67.5) & 15(75) & 0.550 \\ \geq 24 \text { months } & 18(30) & 13(32.5) & 5(25) & \\ \text { Sex } & & & \end{array}$

Sex

$\begin{array}{lllll}\text { Male } & 34(56.7) & 24(60) & 10(50) & 0.461\end{array}$

$\begin{array}{llll}\text { Female } & 26(43.3) & 16(40) & 10(50)\end{array}$

Fever

\begin{tabular}{|c|c|c|c|c|}
\hline$<30$ days & $42(70)$ & $27(67.5)$ & $15(75)$ & $>0.999$ \\
\hline$\geq 30$ days & $18(30)$ & $13(32.5)$ & $5(25)$ & \\
\hline Hepatomegaly & $36(60)$ & $24(60)$ & $12(60)$ & $>0.999$ \\
\hline Splenomegaly & $58(96.7)$ & $39(97.5)$ & $19(95)$ & $>0.999$ \\
\hline Skin lesions & $5(8.3)$ & $5(12.5)$ & $0(0)$ & 0.159 \\
\hline Bleeding tendency & $5(8.3)$ & $5(12.5)$ & $0(0)$ & 0.159 \\
\hline CNS Involvement & $23(38.3)$ & $18(45)$ & $5(25)$ & 0.133 \\
\hline $\begin{array}{l}\text { Abnormal brain } \\
\text { MRI }\end{array}$ & $9(15)$ & $8(20)$ & $1(5)$ & 0.249 \\
\hline $\begin{array}{l}\text { Bone marrow } \\
\text { hemophagocytosis }\end{array}$ & $6(10)$ & $6(15)$ & $0(0)$ & 0.165 \\
\hline Relapse & $6(10)$ & $6(15)$ & $0(0)$ & 0.165 \\
\hline Death & $26(43.3)$ & $26(65)$ & $0(0)$ & $\begin{array}{l}< \\
0.001^{*}\end{array}$ \\
\hline
\end{tabular}

H-score

\begin{tabular}{|c|c|c|c|c|}
\hline$\geq 169$ & $56(93.3)$ & 37 (92.5) & $19(95)$ & \multirow{2}{*}{$\begin{array}{l}> \\
0.999\end{array}$} \\
\hline$<169$ & $4(6.7)$ & $3(7.5)$ & $1(5)$ & \\
\hline$N C<1000 / \mu \mathrm{l}$ & $51(85)$ & $34(85)$ & $17(85)$ & $>0.999$ \\
\hline lemoglobin $<9 \mathrm{~g} /$ & $42(70)$ & $28(70)$ & $14(70)$ & $>0.999$ \\
\hline latelet <100000/ & $40(66.7)$ & $31(77.5)$ & $9(45)$ & $0.012^{*}$ \\
\hline icytopenia & $48(80)$ & $34(85)$ & $14(70)$ & 0.304 \\
\hline $\begin{array}{l}\text { riglyceride }>265 \\
\mathrm{ng} / \mathrm{dL}\end{array}$ & $41(68.3)$ & $28(70)$ & $13(65)$ & 0.695 \\
\hline $\begin{array}{l}\text { ibrinogen <150 } \\
\text { ng/dL }\end{array}$ & 32 (53.3) & $20(50)$ & $12(60)$ & 0.464 \\
\hline \multicolumn{5}{|l|}{ erritin } \\
\hline $500-1000 \mathrm{ng} / \mathrm{ml}$ & $3(5)$ & $3(7.5)$ & $0(0.0)$ & \multirow[t]{3}{*}{0.147} \\
\hline $\begin{array}{l}\text { 1000-10,000 ng/ } \\
\mathrm{ml}\end{array}$ & $41(68.3)$ & $29(72.5)$ & $12(60)$ & \\
\hline$>10000 \mathrm{ng} / \mathrm{ml}$ & $16(26.7)$ & $8(20)$ & $8(40)$ & \\
\hline $\begin{array}{l}\text { erritin, (ng/ml) } \\
\text { nedian (IQR) }\end{array}$ & $\begin{array}{l}4825 \\
(2000.0- \\
10,324.5)\end{array}$ & $\begin{array}{l}3618 \\
(1990.2- \\
9479.2)\end{array}$ & $\begin{array}{l}7122 \\
(3226.2- \\
33,112.2)\end{array}$ & $0.034^{*}$ \\
\hline -dimer > $250 \mathrm{ng} /$ & $59(98.3)$ & $39(97.5)$ & $20(100)$ & $>0.999$ \\
\hline
\end{tabular}
$\mathrm{ml}$
Table 2 Clinical features and laboratory data of patients with primary and visceral leishmaniosis-associated hemophagocytic lymphohistiocytosis (Continued)

\begin{tabular}{|c|c|c|c|c|}
\hline \multirow[t]{2}{*}{ Variables } & \multirow[b]{2}{*}{$\begin{array}{l}\text { All } \\
\text { patients } \\
(n=60) \\
\mathrm{n}(\%)\end{array}$} & \multicolumn{2}{|c|}{ HLH classification } & \multirow{2}{*}{$\begin{array}{l}P \text { - } \\
\text { Value }\end{array}$} \\
\hline & & $\begin{array}{l}\text { Primary } \\
\text { HLH }(n= \\
40) \\
n(\%)\end{array}$ & $\begin{array}{l}\text { VL-associated } \\
\text { HLH }(n=20) \\
\text { n (\%) }\end{array}$ & \\
\hline $\begin{array}{l}\text { PT Prolonged } \\
\text { (age adjusted) }\end{array}$ & $24(40)$ & 15 (37.5) & $9(45)$ & 0.576 \\
\hline $\begin{array}{l}\text { aPTT Prolonged } \\
\text { (age adjusted) }\end{array}$ & $25(41.7)$ & $18(45)$ & $7(35)$ & 0.459 \\
\hline $\begin{array}{l}\text { AST > } \times \text { ULN (IU/ } \\
\text { L) }\end{array}$ & $43(71.7)$ & $30(75)$ & $13(65)$ & 0.418 \\
\hline $\begin{array}{l}\mathrm{ALT}>2 \times \mathrm{ULN}(\mathrm{IU} / \\
\mathrm{L})\end{array}$ & $25(41.7)$ & $21(52.5)$ & $4(20)$ & $0.016^{*}$ \\
\hline $\mathrm{ESR}>20 \mathrm{~mm} / \mathrm{hr}$ & $31(51.7)$ & $16(40)$ & $15(75)$ & $0.011^{*}$ \\
\hline$C R P \geq 6 \mathrm{mg} / \mathrm{L}$ & $53(88.3)$ & $33(82.5)$ & $20(100)$ & 0.084 \\
\hline $\begin{array}{l}{ }^{* *}{ }_{s} \mathrm{CD} 25 \geq 13.1 \mathrm{pg} / \\
\mathrm{mL}\end{array}$ & $14(70)$ & $9(64.3)$ & $5(83.3)$ & 0.613 \\
\hline \multicolumn{5}{|c|}{$\begin{array}{l}V L \text { visceral leishmaniosis, } H L H \text { hemophagocytic lymphohistiocytosis, ULN upper } \\
\text { limit of normal, } A N C \text { absolute neutrophil count, } P T \text { prothrombin time, aPTT } \\
\text { activated partial thromboplastin time, AST aspartate aminotransferase, ALT } \\
\text { alanine aminotransferase, } L D H \text { lactic dehydrogenase, ESR Erythrocyte } \\
\text { sedimentation rate, CRP C-reactive protein, CNS central nervous system, SCD25 } \\
\text { soluble CD25 } \\
\text { "Statistically significant } \\
\text { * }{ }_{\text {sCD25 } 25 \text { was measured in } 20 \text { patients }}\end{array}$} \\
\hline
\end{tabular}

than 24 months. Twenty patients (33.3\%) had VLassociated HLH.

\section{Clinical and laboratory data}

Fever and splenomegaly comprised the most frequent initial clinical findings, with 100 and $96.7 \%$ prevalence, respectively. Similarly, high serum ferritin $(>500 \mathrm{ng} / \mathrm{ml})$ and high serum lactic dehydrogenase (LDH) (>450 U/dL) were found exclusively in all patients. The study population's median serum ferritin was $4825 \mathrm{ng} / \mathrm{ml}$ (range 912-72,000). Extreme hyperferritinemia $(>10,000 \mathrm{ng} / \mathrm{ml})$ was detected in $16(26.7 \%)$ of individuals. sCD25 was measured in one-third of the study population. It was increased in $14(70 \%)$ out of 20 individuals.

The clinical and laboratory characteristics of patients with primary and VL-associated secondary HLH were compared in Table 2. Patients with primary HLH had a more frequently low platelet count of less than 100,000/ $\mu \mathrm{l}(P=0.012)$ and increased alanine transaminase (ALT) $(P=0.016)$ compared to secondary HLH. Moreover, the risk of death was significantly higher in primary HLH $(P<0.001)$. On the other hand, patients with VLassociated HLH had higher serum ferritin $(P=0.034)$. Moreover, they included a higher proportion of patients with high ESR $(>20 \mathrm{~mm} / \mathrm{hr})$ than primary HLH $(P=$ 0.011 ). None of the patients in this group showed skin eruptions, bleeding tendency, or bone marrow 
hemophagocytosis. Nobody experienced disease relapse, and all of them survived.

\section{HScore}

Fifty-six (93.3\%) patients achieved a score $\geq$ of 169 , with no difference in the two groups of primary and secondary HLH $(P>0.99)$. HScore significantly correlated with HLH-2004 criteria $(r=0.371, P=0.004)$.

\section{CNS involvement}

CNS involvement occurred in 23 (38.3\%) patients. The proportion of patients with CNS involvement was not significantly different between primary and secondary HLH groups $(P=0.133)$. In univariate analysis, age $<2$ years $(P=0.024)$, bone marrow hemophagocytosis $(P=$ $0.027)$, and bicytopenia $(P=0.02)$ were associated with CNS involvement (Table 3 ). In subgroup analysis, age $<$ 2 years remained a risk factor in primary HLH $(P=$ $0.016)$. However, no risk factor was found in patients with VL-associated HLH. Binary logistic regression revealed that only age $<2$ years (Odds ratio (OR) 6.446, 95\% CI 1.538-27.012, $P=0.011$ ) increased the odds of CNS involvement. On the other hand, patients with bicytopenia had less chance of neurologic disease (OR $0.073,95 \%$ CI $0.008-0.838, P=0.018)$. Patients with CNS disease had a worse outcome than those without CNS involvement (death rate $61 \%$ vs. 35\%) with marginal statistical significance $(P=0.051)$.

\section{Treatment and outcomes}

During the study period, 33 patients (55\%) showed a treatment response. Twenty-nine patients (87\%) finished their treatment successfully. They were all alive and offtreatment at the end of the study. Treatment was ongoing in 4 more patients with an excellent initial response to treatment. Twenty-six (43.3\%) patients died during treatment that all of them had primary HLH.

Fig. 1 shows the Kaplan-Meier survival curve of the study population during the 40 months follow-up period. The patients experienced a 3-year overall survival (OS) rate of $35.9 \%$, which was significantly lower in the primary HLH than the secondary HLH group (24\% vs. 100\%; $P<0.001)$.

Table 4 demonstrates a univariate analysis of possible covariates associated with the outcome in patients with HLH, assessed by the log-rank test. Among the tested variables, platelet count $<100,000 / \mu \mathrm{l}(P=0.001)$, total bilirubin $>1 \mathrm{mg} / \mathrm{dL} \quad(P=0.008)$, and erythrocyte sedimentation rate $(\mathrm{ESR}) \leq 20 \mathrm{~mm} / \mathrm{hr}$. $(P=0.02)$ were associated with mortality. In Cox regression analysis, platelet count < 100,000/ $\mu$ l (HR 4.472, 95\% CI 1.324-15.107, $P=0.016)$ remained an independent risk factor of mortality.
During the 40 months follow-up period, six patients (10\%) experienced disease relapse. All of them occurred in boys with primary HLH. In multivariable analysis, no independent risk factor was found.

\section{Discussion}

The current study represents the first study on HLH patients in a large referral oncology center in Southern Iran. It is also one of the most extensive case series of secondary HLH associated with VL. It was reported that $\mathrm{VL}$ is associated with about $2 \%$ of all cases of HLH [16]. However, we encountered a much higher prevalence due to VL's high endemicity in Southern Iran, where this study was undertaken. It is good to know that Fars province is one of the central endemic regions of visceral leishmaniasis in southern Iran, with an estimated incidence rate of $0.01 / 10,000$ in 2015 [11]. A recent metaanalysis reported a pooled prevalence of $2.1 \%$ (95\% CI 1.4-2.8\%) of VL in Southern Iran [17]. The first report of a benign hemophagocytic syndrome associated with VL in our region was published by Kumar et al. in 1994 [12]. Mokhtari and Kumar reported the first case series of VL-associated HLH among 13 patients and described their bone marrow characteristics. Hypercellular marrow with erythroid hyperplasia, megaloblastic changes, foamy macrophages, activated macrophages with cytoplasmic vacuoles and elongated cytoplasmic process, intra- and extracellular amastigotes, cytoplasmic fragments (blue bodies), plasma cells with inclusions and hemophagocytic cells, in addition to Leishman bodies (amastigotes) were the most common microscopic findings of the studied patients. The most common hematological abnormalities were anemia (88.8\%), thrombocytopenia (50\%,) and pancytopenia (55.5\%) [13].

The clinical sign and symptoms and laboratory parameters in HLH associated with VL were very similar to primary HLH. Fever and splenomegaly were the most consistent presenting signs and symptoms detected in nearly all patients. Serum ferritin at diagnosis was higher than $900 \mathrm{ng} / \mathrm{ml}$ in all patients, and about $30 \%$ of them had extreme hyperferritinemia (>10,000 ng/ml). However, it did not correlate with disease severity or adverse outcomes such as death or relapse. Allen et al. reported that ferritin level over $10,000 \mathrm{ng} / \mathrm{ml}$ was $90 \%$ sensitive and $96 \%$ specific for HLH [18].

On the other hand, a recent review concluded that HLH is a rare cause of extreme hyperferritinemia, and more common causes such as liver disease and malignancies should be ruled out first [19]. Since timely diagnosis and treatment are directly related to disease outcome, high serum ferritin should raise suspicion to HLH diagnosis if other criteria are met, especially in critically ill patients. 
Table 3 Univariate analysis of covariates associated with central nervous system involvement

\begin{tabular}{|c|c|c|c|c|c|c|c|c|c|}
\hline \multirow{2}{*}{$\begin{array}{l}\text { CNS involvement } \\
\text { Variables }\end{array}$} & \multicolumn{2}{|l|}{ Total } & \multirow[t]{2}{*}{$P$-Value } & \multicolumn{2}{|l|}{ Primary HLH } & \multirow[t]{2}{*}{$P$-Value } & \multicolumn{2}{|c|}{ VL-associated HLH } & \multirow[t]{2}{*}{$P$-Value } \\
\hline & $\begin{array}{l}\text { Yes }(n=23) \\
\text { n (\%) }\end{array}$ & $\begin{array}{l}\text { No }(n=37) \\
n(\%)\end{array}$ & & Yes $(n=18)$ & No $(n=22)$ & & Yes $(n=5)$ & No $(n=15)$ & \\
\hline \multicolumn{10}{|l|}{ Age } \\
\hline$<24$ months & $20(87)$ & $22(59.5)$ & $0.024^{*}$ & $16(88.9)$ & $11(50)$ & $0.016^{*}$ & $4(80)$ & $11(73.3)$ & $>0.999$ \\
\hline$\geq 24$ months & $3(13)$ & $15(40.5)$ & & $2(11.1)$ & $11(50)$ & & $1(20)$ & $4(26.7)$ & \\
\hline \multicolumn{10}{|l|}{ Sex } \\
\hline Male & $16(69.6)$ & $18(48.6)$ & 0.112 & $14(77.8)$ & $10(45.5)$ & 0.054 & $2(40)$ & $8(53.3)$ & $>0.999$ \\
\hline Female & $7(30.4)$ & 19 (51.4) & & $4(22.2)$ & $12(54.5)$ & & $3(60)$ & $7(46.7)$ & \\
\hline Platelet $<100000 / \mu l$ & $18(78.3)$ & $22(59.5)$ & 0.133 & $15(83.3)$ & $16(72.7)$ & 0.476 & $3(60)$ & $6(40)$ & 0.617 \\
\hline Bicytopenia & $22(95.7)$ & $26(70.3)$ & $0.020^{*}$ & $17(94.4)$ & $17(77.3)$ & 0.197 & $5(100)$ & $9(60)$ & 0.260 \\
\hline Fibrinogen $<150 \mathrm{mg} / \mathrm{dL}$ & $9(39.1)$ & $23(62.2)$ & 0.082 & $7(38.9)$ & $13(59.1)$ & 0.341 & $2(40)$ & $10(66.7)$ & 0.347 \\
\hline $\mathrm{ALT}>2 \times \mathrm{ULN}(\mathrm{IU} / \mathrm{L})$ & $12(52.2)$ & $13(35.1)$ & 0.193 & $12(66.7)$ & $9(40.9)$ & 0.125 & $0(0)$ & $4(26.7)$ & 0.530 \\
\hline BM. hemophagocytosis & $5(21.7)$ & $1(2.7)$ & $0.027^{*}$ & $5(27.8)$ & $1(4.5)$ & 0.073 & $0(0)$ & $0(0)$ & - \\
\hline Bleeding tendency & $4(17.4)$ & $1(2.7)$ & 0.066 & $4(22.2)$ & $1(4.5)$ & 0.155 & $0(0)$ & $0(0)$ & - \\
\hline
\end{tabular}

ULN upper limit of normal, ALT alanine aminotransferase, BM bone marrow, CNS central nervous system "statistically significant

Patients with VL-associated HLH experienced higher serum ferritin and ESR. Though the underlying infection may be a simple explanation, enhanced ferroportinmediated iron efflux due to overexpression of growth differentiation factor 15 may play a role [20]. On the other hand, primary HLH was associated with more severe thrombocytopenia, higher ALT, and worse outcome than secondary HLH. Koh et al. reported that splenomegaly, bicytopenia, $\mathrm{Hb}<9 \mathrm{~g} / \mathrm{dL}$, and platelets < $100,000 / \mu \mathrm{l}$ were more frequently encountered in patients with primary HLH. They also reported a lower 5-yr OS in primary HLH compared to secondary HLH [21]. Some of the mentioned features, such as bicytopenia and thrombocytopenia, can be regarded as markers of disease severity, directly linked to poor survival. We came across a similar result in which thrombocytopenia served as an independent risk factor of death, especially in patients with primary HLH.

Nearly $40 \%$ of our patients had evidence of CNS involvement. The rate of CNS involvement in HLH varies in different studies ranging from 18 to $73 \%$ [22]. Some reported previously that patients with CNS disease had lower ferritin, AST, and ALT than those without CNS involvement [23]. We did not find such an association in our patients except that children younger than 2 years had more than a 6-fold higher chance of CNS disease

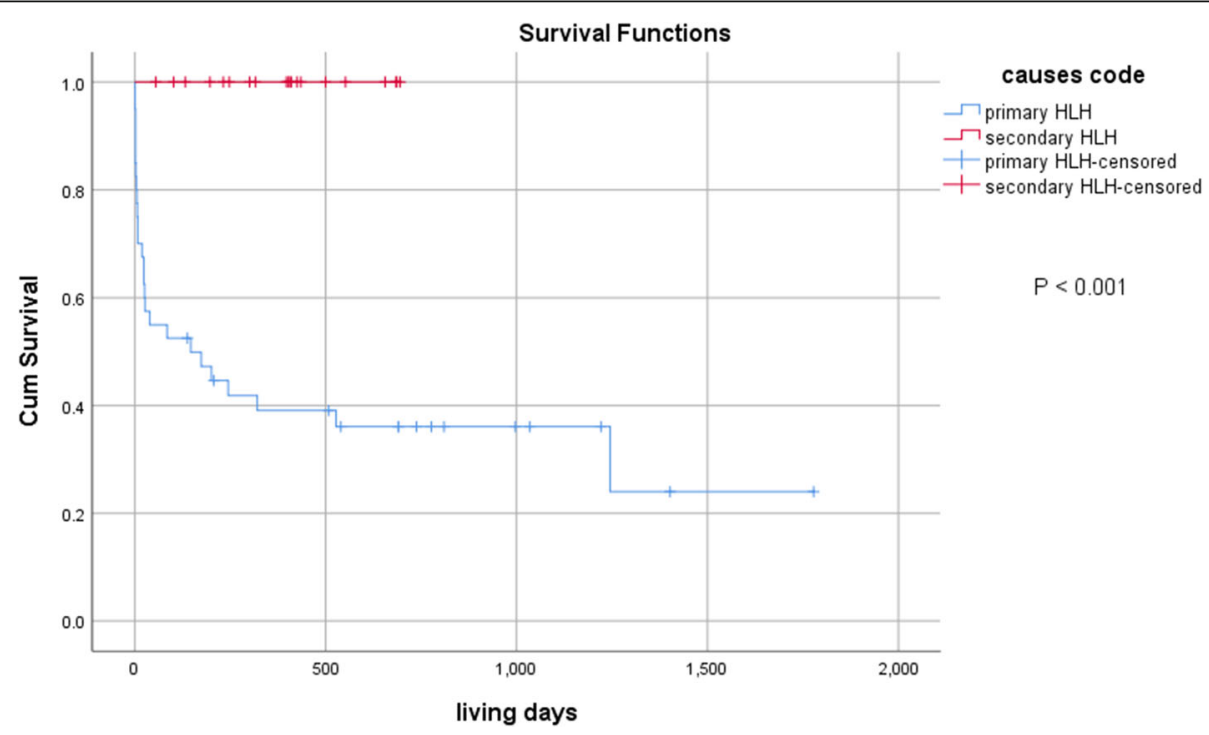

Fig. 1 Kaplan-Meier survival curve of patients with hemophagocytic lymphohistiocytosis 
Table 4 Univariate analysis of covariates associated with mortality in patients with primary hemophagocytic lymphohistiocytosis

\begin{tabular}{|c|c|c|}
\hline Variables & $\begin{array}{l}\text { Mean survival in days } \\
\text { (95\% confidence interval) }\end{array}$ & $P$-value \\
\hline \multicolumn{3}{|l|}{ Splenomegaly } \\
\hline Yes & $935.9(678.5-1193.4)$ & \multirow[t]{2}{*}{0.069} \\
\hline No & $37(1.72-72.3)$ & \\
\hline \multicolumn{3}{|c|}{ BM. hemophagocytosis } \\
\hline Yes & $146.0(24.9-267.1)$ & \multirow[t]{2}{*}{0.059} \\
\hline No & $977.2(710.2-1244.2)$ & \\
\hline \multicolumn{3}{|l|}{ CNS involvement } \\
\hline Yes & $655.6(304.0-1007.0)$ & \multirow[t]{2}{*}{0.092} \\
\hline No & $849.3(657.7-1040.9)$ & \\
\hline \multicolumn{3}{|c|}{ Bleeding tendency } \\
\hline Yes & $195.8(24.5-367.1)$ & \multirow[t]{2}{*}{0.059} \\
\hline No & $960.1(695.9-1224.2)$ & \\
\hline \multicolumn{3}{|l|}{ Bicytopenia } \\
\hline Yes & 801.7 (540.0-1063.4) & \multirow[t]{2}{*}{0.052} \\
\hline No & $845.2(652.5-1037.8)$ & \\
\hline \multicolumn{3}{|l|}{ Platelet count } \\
\hline$<100,000 / \mu \mathrm{L}$ & $711.2(443.8-978.7)$ & \multirow[t]{2}{*}{$0.001^{*}$} \\
\hline$\geq 100,000 / \mu \mathrm{L}$ & $1195.2(1001.1-1389.3)$ & \\
\hline \multicolumn{3}{|l|}{ Hemoglobin } \\
\hline$<9 \mathrm{~g} / \mathrm{dL}$ & $844.0(562.9-1125.2)$ & \multirow[t]{2}{*}{0.188} \\
\hline$\geq 9 \mathrm{~g} / \mathrm{dL}$ & $808.1(547.3-1068.9)$ & \\
\hline \multicolumn{3}{|l|}{ Total bilirubin } \\
\hline$>1 \mathrm{mg} / \mathrm{dL}$ & $571.2(275.5-867.0)$ & \multirow[t]{2}{*}{$0.008^{*}$} \\
\hline$\leq 1 \mathrm{mg} / \mathrm{dL}$ & 1004.3 (781.7-1226.8) & \\
\hline \multicolumn{3}{|l|}{ ESR } \\
\hline$>20 \mathrm{~mm} / \mathrm{hr}$ & $1271.7(934.8-1608.6)$ & \multirow[t]{2}{*}{$0.002^{*}$} \\
\hline$\leq 20 \mathrm{~mm} / \mathrm{hr}$ & $459.4(298.7-620.1)$ & \\
\hline \multicolumn{3}{|l|}{ Fibrinogen } \\
\hline$<150 \mathrm{mg} / \mathrm{dL}$ & $1001.8(660.1-1343.5)$ & \multirow[t]{2}{*}{0.183} \\
\hline$\geq 150 \mathrm{mg} / \mathrm{dL}$ & $658.7(405.4-912.1)$ & \\
\hline
\end{tabular}

ULN upper limit of normal, ALT alanine aminotransferase, ESR Erythrocyte sedimentation rate, CNS central nervous system, BM bone marrow The data were analyzed by the Log-rank test; only variables with $P<0.2$ are shown

*Statistically significant

than older patients. Moreover, bicytopenia decreased the probability of CNS involvement by $93 \%$.

Many reports are indicating that CNS involvement might be associated with worse outcomes (19). Although the overall mortality rate was higher in those with CNS events, this association was not shown in multivariable analysis. It is generally agreed that CNS involvement poses a higher risk of relapse unless hematopoietic stem cell transplantation (HSCT) is undergone early after starting systemic therapy [22].

HScore had a good correlation with HLH-2004 criteria for the diagnosis of HLH in our study. It was reported that HScore carries a diagnostic sensitivity of $90 \%$ and specificity of $79 \%$ for HLH [6]. A cutoff of 169 had $93 \%$ sensitivity and $86 \%$ specificity for HLH [24]. Similarly, more than $90 \%$ of our confirmed cases of HLH had HScore $\geq 169$. Given the unavailability of sCD25 and natural killer (NK) cell activity in some centers, HScore can be utilized to make early diagnosis and treatment in case of incomplete criteria.

The treatment response was 55\% in our study cohort with a 3 -yr OS rate of $36 \%$. It was much lower in patients with primary HLH than secondary HLH (24\% vs. $100 \%)$. All patients with VL-associated HLH were successfully treated with liposomal amphotericin. Nobody needed to be treated with etoposide or cyclosporine. Dexamethasone was initially 
started in a few patients with severe disease but was tapered and discontinued after a few weeks. The outcome was excellent, with no report of death or HLH relapse during the 40 months follow-up. Targeted treatment of the etiologic pathogen usually is the only treatment strategy recommended in secondary infection-associated HLH such as brucella and leishmania. Specific antimicrobial therapy usually is associated with complete recovery in most cases [25-31].

High-dose intravenous gamma-globulin (IVIG) has been used successfully in viral-associated hemophagocytic syndrome [32]; however, none of our cases were treated with IVIG.

Platelet count less than $100,000 / \mu \mathrm{l}$ was independently associated with more than four times the increased risk of death in our patients with primary HLH. The outcome of patients with HLH and associated prognostic factors differ among different studies. A recent study in Japan reported a much better outcome in their patients with a 3-yr OS rate of 74\% [33]. Koh et al. reported a 5 -yr OS rate of $68 \%$ in their study cohort, which was worse (38\%) in primary HLH patients. They concluded that lower age at diagnosis, severe transaminasemia, and coagulation abnormality were independent risk factors of survival [21]. In other studies, decreased serum albumin level, LDH $\geq 3707 \mathrm{U} / \mathrm{L}, \mathrm{IL}-10 \geq 456 \mathrm{pg} / \mathrm{ml}$, neutrophil count $<500 / \mu \mathrm{l}$, and total bilirubin $>2 \times$ normal upper limit was associated with a higher mortality rate [34-36].

Our study faced some limitations. Firstly, some specific laboratory tests, such as NK cell function, were unavailable in our center. Besides, $\mathrm{sCD} 25$ was measured in a portion of our patients since it was available in our center in 2017. These tests' unavailability might lead to a delayed diagnosis and poor outcome, evident as a lower 3-yr OS rate in our study cohort than many other reports.

\section{Conclusion}

VL is a potential source of secondary HLH in regions with high endemicity. The main clinical findings and complications such as CNS involvement are the same as primary HLH. It is associated with higher serum ferritin and ESR but a lower incidence of thrombocytopenia and transaminitis than primary HLH. Treatment of the underlying disease in VL-associated HLH is sufficient in most cases, with no need to start etoposide-based chemotherapy. The prognosis is excellent, with no reported death or recurrence of disease in our case series.

\section{Abbreviations}

HLH: Hemophagocytic lymphohistiocytosis; VL: Visceral leishmaniasis; CNS: Central nervous system; EBV: Epstein-Barr virus; CMV: Cytomegalovirus; RT-PCR: Real-time polymerase chain reaction; sCD25: Soluble CD25; MRI: Magnetic resonance imaging; SPSS: Statistical Package for the Social Sciences; IQR: Interquartile range; Cl: Confidence interval; HR: Hazard ratio; ALT: Alanine transaminase; AST: Aspartate transaminase; OR: Odds ratio; NK cell: Natural killer cell; OS: Overall survival; LDH: Lactate dehydrogenase; IL10: Interleukin 10; HSCT: Hematopoietic stem cell transplantation;
ESR: Erythrocyte sedimentation rate; ULN: Upper limit of normal; BM: Bone marrow; HIV: Human immunodeficiency virus; aPTT: Activated partial thromboplastin time; PT: Prothrombin time; SGOT: Serum glutamicoxaloacetic transaminase; HB: Hemoglobin; WBC: White blood cell; PLT: Platelet; ANC: Absolute neutrophil count; CRP: C-reactive protein

\section{Acknowledgments}

This study was relevant to the fellowship thesis of $\mathrm{H}$. Mottaghipisheh with project No. 13253. We would like to thank the Shiraz University of Medical Sciences for financial support. We appreciate MS. Parand for her assistance in submitting the article.

\section{Authors' contributions}

$\mathrm{HM}$ and MB contributed to the concept and design of the study. KK and MS did and interpreted laboratory tests. SH performed statistical analysis. HM gathered the data. MB wrote the initial draft. All the authors reviewed the drafts, provided critical comments, and approved the final manuscript.

\section{Funding}

This research was funded by the Research Vice-Chancellor of Shiraz University of Medical Sciences.

\section{Availability of data and materials}

The data presented in this study are available on request from the corresponding author

\section{Declarations}

Ethics approval and consent to participate

The study protocol was approved by the Ethics Committee of Shiraz University of Medical Sciences (IR.SUMS.REC.1399.1281). Also, all methods were carried out in accordance with Declaration of Helsinki.

A written informed consent form was signed by the parents or the legal guardians of the participants.

\section{Consent for publication}

Not applicable.

\section{Competing interests}

The authors declare that they have no conflict of interest.

\section{Author details}

${ }^{1}$ Hematology Research Center, Shiraz University of Medical Sciences, Shiraz, Iran. ${ }^{2}$ Department of Immunology, School of Medicine, Shiraz University of Medical Sciences, Shiraz, Iran. ${ }^{3}$ Professor Alborzi Clinical Microbiology Research Center, Amir Oncology Hospital, Shiraz University of Medical Sciences, Shiraz, Iran. ${ }^{4}$ Department of Pathology, School of Medicine, Shiraz University of Medical Sciences, Shiraz, Iran. ${ }^{5}$ Department of Pediatrics, Nemazi Hospital, Shiraz University of Medical Sciences, Shiraz, Iran.

Received: 19 April 2021 Accepted: 20 July 2021

Published online: 02 August 2021

\section{References}

1. Filipovich A, McClain K, Grom A. Histiocytic disorders: recent insights into pathophysiology and practical guidelines. Biol Blood Marrow Transplant. 2010;16(1 Suppl):S82-9. https://doi.org/10.1016/j.bbmt.2009.11.014.

2. Henter JI, Elinder G, Söder O, Ost A. Incidence in Sweden and clinical features of familial hemophagocytic lymphohistiocytosis. Acta Paediatr Scand. 1991;80(4):428-35. https://doi.org/10.1111/j.1651-2227.1991.tb11878.x.

3. Ricaurte FR, Kewan T, Chadalavada P, Misbah S, Daw H. Hemophagocytic Lymphohistiocytosis associated with natural T-cell leukemia. Cureus. 2019; 11(2):e4107. https://doi.org/10.7759/cureus.4107.

4. Jordan MB, Allen CE, Weitzman S, Filipovich AH, McClain KL. How I treat hemophagocytic lymphohistiocytosis. Blood. 2011;118(15):4041-52. https:// doi.org/10.1182/blood-2011-03-278127.

5. Larroche C. Hemophagocytic lymphohistiocytosis in adults: diagnosis and treatment. Joint Bone Spine. 2012;79(4):356-61. https://doi.org/10.1016/j. jbspin.2011.10.015.

6. Debaugnies F, Mahadeb B, Ferster A, Meuleman N, Rozen L, Demulder A, et al. Performances of the $\mathrm{H}$-score for diagnosis of Hemophagocytic 
Lymphohistiocytosis in adult and pediatric patients. Am J Clin Pathol. 2016; 145(6):862-70. https://doi.org/10.1093/ajcp/aqw076.

7. Esteban YM, de Jong JLO, Tesher MS. An overview of Hemophagocytic Lymphohistiocytosis. Pediatr Ann. 2017;46(8):e309-13. https://doi.org/10.392 8/19382359-20170717-01.

8. Shamsian BS, Rezaei N, Alavi S, Hedayat M, Amin Asnafi A, Pourpak Z, et al. Primary hemophagocytic lymphohistiocytosis in Iran: report from a single referral center. Pediatr Hematol Oncol. 2012;29(3):215-9. https://doi.org/1 0.3109/08880018.2012.657338.

9. Ghanaie R, Shiari R, KARIMI AE, Armin S, Fahimzad A, Shiva F, et al. A case series report of Iranian children, hemophagocytic lymphohistiocytosis syndrome; 2012.

10. Shamsian BS, Nikoufar M, Esfahani SA, Shamshiri AR, Arzanian MT, Alavi S, et al. A 10-year single center survey of pediatric patients with histiocytic disorders in Iran. Turk J Pediatr. 2011:53(1):34-42.

11. World Health Organization. Leishmaniasis. 2020; https://www.whoint/ leishmaniasis/burden/Leishmaniasis_Iran/en/ Accessed 11 Apr 2020.

12. Alborzi A, POULADFAR GR, AALAMI MH. Visceral leishmaniasis; literature review and Iranian experience. Iran J of Clin Infect Dis. 2007;2(2):99-108.

13. Mokhtari M, Kumar PV. Visceral leishmaniasis-associated hemophagocytosis: a single center experience. Arch Iran Med. 2013;16(8):471-3.

14. Henter Jl, Horne A, Aricó M, Egeler RM, Filipovich AH, Imashuku S, et al. $\mathrm{HLH}-2004$ : diagnostic and therapeutic guidelines for hemophagocytic lymphohistiocytosis. Pediatr Blood Cancer. 2007;48(2):124-31. https://doi. org/10.1002/pbc.21039.

15. Krepis P, Argyri I, Krepi A, Syrmou A, Spyridis N, Tsolia M. Short-course regimens of liposomal amphotericin $B$ for the treatment of Mediterranean visceral Leishmaniasis in children: an 11-year retrospective study at a tertiary care center. Pediatr Infect Dis J. 2017;36(9):849-54. https://doi.org/10.1097/ INF.0000000000001602.

16. Bode SF, Bogdan C, Beutel K, Behnisch W, Greiner J, Henning S, et al. Hemophagocytic lymphohistiocytosis in imported pediatric visceral leishmaniasis in a nonendemic area. J Pediatr. 2014;165(1):147-153.e141.

17. Rostamian M, Bashiri H, Yousefinejad V, Bozorgomid A, Sohrabi N, Raeghi S, et al. Prevalence of human visceral leishmaniasis in Iran: A systematic review and meta-analysis. Comp Immunol Microbiol Infect Dis. 2021;75:101604.

18. Allen CE, Yu X, Kozinetz CA, McClain KL. Highly elevated ferritin levels and the diagnosis of hemophagocytic lymphohistiocytosis. Pediatr Blood Cancer. 2008:50(6):1227-35. https://doi.org/10.1002/pbc.21423.

19. Suman S, Ahmed A. Extreme hyperferritinemia does not equal to HLH. Int J Clin Rheumatol. 2019;14(4):134-5.

20. Wu JR, Yuan LX, Ma ZG, Chen XX, Gu L, Gao J. GDF15-mediated upregulation of ferroportin plays a key role in the development of hyperferritinemia in children with hemophagocytic lymphohistiocytosis. Pediatr Blood Cancer. 2013;60(6):940-5. https://doi.org/10.1002/pbc.24373.

21. Koh KN, Im HJ, Chung NG, Cho B, Kang HJ, Shin HY, et al. Clinical features, genetics, and outcome of pediatric patients with hemophagocytic lymphohistiocytosis in Korea: report of a nationwide survey from Korea Histiocytosis working party. Eur J Haematol. 2015;94(1):51-9. https://doi. org/10.1111/ejh.12399.

22. Horne A, Wickström R, Jordan MB, Yeh EA, Naqvi A, Henter Jl, et al. How to treat involvement of the central nervous system in Hemophagocytic Lymphohistiocytosis? Curr Treat Options Neurol. 2017;19(1):3. https://doi. org/10.1007/s11940-017-0439-4.

23. Kim MM, Yum MS, Choi HW, Ko TS, Im HJ, Seo JJ, et al. Central nervous system (CNS) involvement is a critical prognostic factor for hemophagocytic lymphohistiocytosis. Korean J Hematol. 2012;47(4):273-80. https://doi.org/10. 5045/kjh.2012.47.4.273.

24. Soy M, Atagündüz $P$, Atagündüz I, Sucak GT. Hemophagocytic lymphohistiocytosis: a review inspired by the COVID-19 pandemic Rheumatol Int. 2021:41(1):7-18. https://doi.org/10.1007/s00296-020-04636-y.

25. Cançado GG, Freitas GG, Faria FH, de Macedo AV, Nobre V. Hemophagocytic lymphohistiocytosis associated with visceral leishmaniasis in late adulthood. Am J Trop Med Hyg. 2013;88(3):575-7. https://doi.org/1 0.4269/ajtmh.12-0563.

26. Matnani R, Ganapathi KA. Hemophagocytic lymphohistiocytosis associated with visceral leishmaniasis. Blood. 2016;127(4):513. https://doi.org/10.1182/ blood-2015-10-678862

27. Tapisiz A, Belet N, Ciftçi E, Ince E, Dogru U. Hemophagocytic lymphohistiocytosis associated with visceral leishmaniasis. J Trop Pediatr. 2007:53(5):359-61. https://doi.org/10.1093/tropej/fmm024.
28. Scalzone M, Ruggiero A, Mastrangelo S, Trombatore G, Ridola V, Maurizi P, et al. Hemophagocytic lymphohistiocytosis and visceral leishmaniasis in children: case report and systematic review of literature. J Infect Dev Ctries. 2016;10(1):103-8. https://doi.org/10.3855/jidc.6385.

29. Rajagopala S, Dutta U, Chandra KS, Bhatia P, Varma N, Kochhar R. Visceral leishmaniasis associated hemophagocytic lymphohistiocytosis--case report and systematic review. J Inf Secur. 2008;56(5):381-8.

30. El Euch M, Kaabar MY, Bouaziz R, Mahfoudhi M, Jaziri F, Kefi A, et al. Successful resolution of Hemophagocytic lymphohistiocytosis associated to brucellosis in the adult. Tunis Med. 2018;96(7):458-61.

31. Yaman Y, Gözmen S, Özkaya AK, Oymak Y, Apa H, Vergin C, et al. Secondary hemophagocytic lymphohistiocytosis in children with brucellosis: report of three cases. J Infect Dev Ctries. 2015;9(10):1172-6. https://doi.org/10.3855/ jidc.6090.

32. Larroche C, Bruneel F, André MH, Bader-Meunier B, Baruchel A, Tribout B, et al. Intravenously administered gamma-globulins in reactive hemaphagocytic syndrome. Multicenter study to assess their importance, by the immunoglobulins group of experts of CEDIT of the AP-HP. Ann Med Interne (Paris). 2000;151(7):533-9.

33. Yanagisawa R, Nakazawa Y, Matsuda K, Yasumi T, Kanegane H, Ohga S, et al Outcomes in children with hemophagocytic lymphohistiocytosis treated using HLH-2004 protocol in Japan. Int J Hematol. 2019;109(2):206-13. https://doi.org/10.1007/s12185-018-02572-z.

34. Oguz MM, Sahin G, Altinel Acoglu E, Polat E, Yucel H, Oztek Celebi FZ, et al. Secondary hemophagocytic lymphohistiocytosis in pediatric patients: a single center experience and factors that influenced patient prognosis. Pediatr Hematol Oncol. 2019;36(1):1-16. https://doi.org/10.1080/08880018.2 019.1572253.

35. Luo ZB, Chen YY, Xu XJ, Zhao N, Tang YM. Prognostic factors of early death in children with hemophagocytic lymphohistiocytosis. Cytokine. 2017;97:805. https://doi.org/10.1016/j.cyto.2017.03.013.

36. Bin Q, Gao JH, Luo JM. Prognostic factors of early outcome in pediatric hemophagocytic lymphohistiocytosis: an analysis of 116 cases. Ann Hematol. 2016;95(9):1411-8. https://doi.org/10.1007/s00277-016-2727-6.

\section{Publisher's Note}

Springer Nature remains neutral with regard to jurisdictional claims in published maps and institutional affiliations.

Ready to submit your research? Choose BMC and benefit from:

- fast, convenient online submission

- thorough peer review by experienced researchers in your field

- rapid publication on acceptance

- support for research data, including large and complex data types

- gold Open Access which fosters wider collaboration and increased citations

- maximum visibility for your research: over $100 \mathrm{M}$ website views per year

At $\mathrm{BMC}$, research is always in progress.

Learn more biomedcentral.com/submissions 